Working Paper No. 58 - January 2011

FEDERALISM AND INTERGOVERNMENTAL RELATIONS : THE MULTI-LEVEL POLITICS OF CLIMATE CHANGE POLICY IN BELGIUM

Sander Happaerts Simon Schunz Hans Bruyninckx

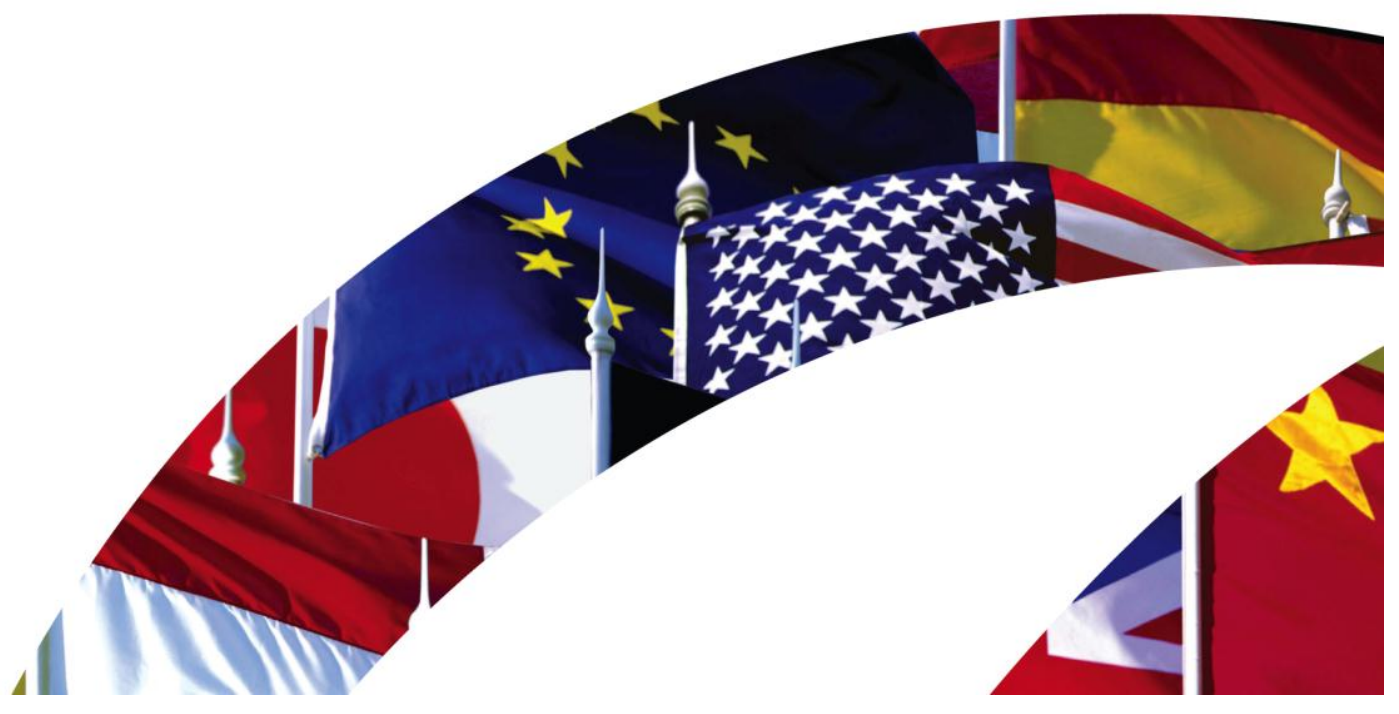




\title{
FEDERALISM AND INTERGOVERNMENTAL RELATIONS : The Multi-Level Politics Of Climate Change Policy In Belgium
}

\author{
Sander Happaerts, Simon Schunz, Hans Bruyninckx
}

\section{ABstract}

The paper discusses the relations between the different layers of government in Belgium with regard to a typical multi-level issue, i.e. climate change. It addresses the question to which degree the characteristics of Belgian federalism shape those intergovernmental relations. Three major characteristics are identified: the constitutionally 'dual' but de facto 'cooperative' federalism, the Europeanization of competences and of relations, and the executive and politicized character of federalism. The impact of those characteristics are studied with regard to crucial cases in recent decision-making on (i) domestic climate change policy in Belgium and on (ii) the position and representation of Belgium in the international climate change debate.

It is observed that intergovernmental relations on climate change are to a high degree institutionalized. That is the consequence of the fragmentation in many of the competence areas important for climate change (e.g. environment, energy, transport). The different cooperation mechanisms are based on consensus, as a consequence of the principle of no hierarchy between the two levels of government. Since climate change is a highly sensitive issue involving important interests, consensus-based decision-making has led to lengthy and difficult discussions. In the complex Belgian setting, the EU is often the number one reason to bring the different governments around the same table. Intergovernmental relations on climate change policy in Belgium are triggered by formal requests by the EU to take a stance or deliver certain policy outputs on specific issues. Yet international requirements and deadlines are unable to break domestic gridlock due to political stalemates. Intergovernmental relations are completely controlled by political parties and ministerial cabinets. That becomes problematic in a context of political asymmetry, where the distinct levels of government are ruled by different coalitions. In the case of climate change, the opposition between conservative and progressive climate goals has meant that Belgium was unable to take a stance in recent debates, and it increases the probability of policy failures. 


\section{KEY WORDS}

Belgium - climate change - EU Presidency - Europeanization - federalism intergovernmental relations

\section{AUTHOR(s)}

Sander Happaerts is a research fellow and $\mathrm{PhD}$ candidate at the Institute for International and European Policy and a member of the Leuven Centre for Global Governance Studies.

Dr. Simon Schunz is a postdoctoral research fellow in the project 'Global Governance and Democratic Government' at the Leuven Centre for Global Governance Studies.

Dr. Hans Bruyninckx is the director of HIVA (Research Institute for Work and Society), professor of international relations at the Institute for International and European Policy and a senior member of the Leuven Centre for Global Governance Studies.

\section{ADDRESS FOR CORRESPONDENCE}

sander.happaerts@soc.kuleuven.be simon.schunz@soc.kuleuven.be

hans.bruyninckx@hiva.kuleuven.be

(C) 2011 by Sander Happaerts, Simon Schunz, Hans Bruyninckx. All rights reserved. No portion of this paper may be reproduced without permission of the authors.

Working papers are research materials circulated by their authors for purposes of information and critical discussion. They have not necessarily undergone formal peer review. 


\section{CONTENTS}

1. INTRODUCTION

2. BELGIAN FEDERALISM : DETERMINING INTERGOVERNMENTAL 5 RELATIONS?

2.1 DUAL IN THEORY, COOPERATIVE IN PRACTICE

2.2 EUROPEANIZATION OF INTERGOVERNMENTAL RELATIONS

8

2.3 EXECUTIVE FEDERALISM AND POLITICIZED RELATIONS

9

3. INTERGOVERNMENTAL RELATIONS ON DOMESTIC CLIMATE CHANGE 11 POLICY IN BELGIUM

3.1 NEGOTIATING A BURDEN SHARING AGREEMENT

3.2 FORGING A NATIONAL ACTION PLAN

3.3 FEDERAL AND SUBNATIONAL CLIMATE CHANGE POLICIES

4. INTERGOVERNMENTAL RELATIONS ON THE BELGIAN POSITION AND 19 REPRESENTATION IN INTERNATIONAL DECISION-MAKING ON CLIMATE CHANGE

4.1 DEFINING A BELGIAN POSITION FOR EU AND GLOBAL 20 NEGOTIATIONS ON CLIMATE CHANGE

4.2 REPRESENTING THE BELGIAN POSITION IN EU AND GLOBAL 23 NEGOTIATIONS ON CLIMATE CHANGE

4.3 SUBNATIONAL GOVERNMENTS ON THE INTERNATIONAL SCENE

5. CONCLUSIONS

26 


\section{INTRODUCTION}

Climate change is a global commons problem. From an environmental governance perspective, it needs to be tackled at all levels of governance, from the global to the local. While general targets are often negotiated at the international level, governments at lower levels (national, subnational and local) design context-specific policies and are responsible for implementation. Moreover, climate change touches upon different sectors, such as environment, energy, agriculture and transport. It thus requires joint and coordinated action between and within governments. Especially in multi-level states, where competences are shared between national and subnational governments, climate change poses several coordination and cooperation challenges.

Our focus in this contribution is on Belgium, a small and highly federalized country in Western Europe. Concretely, the paper conceptualizes and analyzes the link between Belgian federalism and intergovernmental relations on climate change policy. We identify and theorize the factors that determine the shape of those relations, and explore whether they are conflict-ridden or not. To that end, 'intergovernmental relations' are understood as the relations between the federal government and the subnational governments in Belgium. We do not focus on the set-up of those relations per se, but mostly on their functioning and on how they are used to produce policy decisions. The paper considers decision-making with regard to (i) a domestic climate change policy in Belgium and (ii) the Belgian position and representation in European and global forums of climate change policy. Emphasis is placed on a select number of crucial cases in the recent and current decision-making processes on climate change, but we do not elaborate on the implementation or evaluation of climate change policies.

The paper is based on a literature review regarding federalism and Belgian climate change policy, on the study of relevant policy documents, on several interviews with policy officials, and on non-participant observation. ${ }^{1}$ The analysis proceeds as

\footnotetext{
${ }^{1}$ The second and third authors of this paper were members of the Belgian delegation at COP15 in Copenhagen in 2009 and followed the preparatory decision-making process at all levels of governance.
} 
follows: the next section explores some crucial characteristics of Belgian federalism that are assumed to potentially influence intergovernmental relations on climate change policy (2.). Subsequently, those intergovernmental relations are studied, first with regard to the domestic climate change policy in Belgium (3.), and second with regard to the position and representation of Belgium in the climate debate at the European and global level (4.). Conclusions are presented in a final section (5.).

\section{BELGIAN FEDERALISM : DETERMINING INTERGOVERNMENTAL RELATIONS ?}

While it could be said that all political systems are different and to a certain extent unique, Belgium, with its complex federal architecture, is probably more unique than others (Peters 2006: 1079). As part of a gradual reform process, Belgium officially became a federal state in 1993. It has two types of subnational governments (or 'federated entities'): three Regions (Flanders, Wallonia and Brussels) and three Communities (Flemish, French and German-speaking). ${ }^{2}$ In this paper, we highlight three particular characteristics of the Belgian system which, we assume, are most likely to determine intergovernmental relations on climate change policy. By conceptualizing those characteristics and subsequently applying them to our topic, we intend to explain how Belgian federalism shapes intergovernmental relations on climate change policy. The three characteristics we focus on are: the constitutionally 'dual' but de facto 'cooperative' federalism (2.1), the Europeanization of intergovernmental relations (2.2), and executive and politicized relations (2.3). They relate to the internal institutional context, to the external policy environment, and to the political character of Belgian federalism.

\subsection{DUAL IN THEORY, COOPERATIVE IN PRACTICE}

Federal states are traditionally categorized into dual or cooperative systems (Braun 2000: 4). In dual federalism, powers are neatly divided between the two levels of government, and both levels can operate autonomously from one another. In cooperative federalism, powers are not so much divided but rather shared between levels (e.g. one level can hold the legislative powers in a certain matter while the other level implements the decisions), which makes that strong intergovernmental

The authors would like to thank the interviewed officials for their valuable input and their feedback on an earlier draft.

${ }^{2}$ Many laudable efforts to describe and analyze Belgian federalism have been made (e.g. Jans and Tombeur 2000; Swenden et al. 2006). 
cooperation is built into the system. In reality, few countries fall completely into one of the two categories, but are rather situated on a continuum between a dual and a cooperative end (Swenden 2006: 49).

On that continuum, the Belgian Constitution places Belgium clearly in the group of dual federations. Competences are divided on a strictly exclusive basis, which means that all aspects (i.e. legislative and executive) of each competence can only pertain to one level of government (Swenden and Jans 2006: 886). The Regions have competences in 'territorial' matters such as environment, spatial planning, agriculture, economic development, foreign trade, energy policy, transport or infrastructure. The Communities have competences in 'personal' matters such as education, language policy or culture (Hooghe et al. 2008: 185-186; Swenden et al. 2006: 865-868). ${ }^{3}$ As the federalization of Belgium grew out of the ethno-linguistic cleavage between Flemings and francophones, the rationale behind the exclusive character of competences was to avoid as much as possible that Flemish and francophone politicians would have to take decisions together (Swenden and Jans 2006: 886). In addition, there is no hierarchy between federal and subnational laws (Swenden 2006: 54). As a consequence, unlike in many other multi-level states, the federal government cannot impose anything on the subnational governments, and the latter are not bound by federal legislation. Everything that transcends one level of government-and that could thus be considered as truly 'national'-requires a consensus among the federal and all the subnational governments. Furthermore, the exclusivity of competences extends to Belgium's foreign policy. The in foro interno, in foro externo principle prescribes that the subnational governments can conduct an external policy for those policy issues for which they are internally competent. That implies that they can include representatives in national delegations for global negotiations and that they can 'speak' at the international level (Van den Brande et al. 2011). For instance, for certain matters that relate to subnational competences, subnational ministers represent Belgium in the European Union (EU) Council of Ministers (e.g. Industry, Environment, Fisheries). The principle also implies that the federal government can only speak for Belgium when strictly federal competences are at stake.

One of the problems related to the dual character of Belgian federalism is the risk of policy failures (Maesschalck and Van De Walle 2006). Because of the exclusivity of competences, it is perfectly possible that the subnational governments conduct totally diverging or even contradictory policies in certain domains (see, for instance, De Rynck and Dezeure 2006). In reality, policy-making on one side of the language

\footnotetext{
${ }^{3}$ Since the Communities have no relevant competences in the area of climate change, they will not be considered in our analysis.
} 
border often happens without knowing what the other side is doing. At the Flemish side, that is reinforced by the popular adage 'what we do ourselves, we do better' (Maesschalck and Van De Walle 2006: 1012), even in cases where it is obvious that policy coordination would enhance effectiveness.

Yet, if the constitutional reforms had the intended result of neatly dividing all powers in order for both levels to operate in complete autonomy, they have to be considered as a failure. The allocation happened in such a way that there are no fully coherent competence packages in any domain. That fragmentation is obvious in many areas important for climate change. For instance, in the environmental domain, the Regions are largely competent but the federal government retains the responsibility over certain aspects such as product standardization, protection against radiation and transit of waste. Regarding energy, the Regions have the competence over renewable energy policy and rational energy use, but the federal government controls nuclear energy and off-shore wind energy. As for transport policy, road transport, seaports, regional airports and public transport are subnational competences but rail transport and the national airport are federal responsibilities (FOD VVVL 2008b). Moreover, the federal government has the control over taxation, a policy instrument that is important in all policy domains. Indeed, while the spending autonomy of the subnational governments is very large, their power to levy taxes is limited (Swenden and Jans 2006: 885). ${ }^{4}$

As a consequence of the incoherent allocation of competences, the different levels of government are highly dependent on one another if they want to attain a minimum degree of policy coherence, and certainly of effectiveness. That means that, in practice, dual federalism is a fiction (Swenden and Jans 2006: 886). The most typical instrument of the 'cooperative' character of Belgian federalism are the so-called 'cooperation agreements'. Those are agreements concluded between the federal and the subnational governments, on any topic considered relevant, in order to enhance cooperation. The agreements allow the governments to develop common policies or to jointly exercise their competences in a certain domain (Jans and Tombeur 2000: 148). Several hundreds of such cooperation agreements have been concluded. Since their development happens through negotiations between equally 'sovereign' actors, and because in some cases the agreements have to be ratified by the concerned parliaments, it is very similar to the conclusion of international treaties (and can take equally as long). That is why it is sometimes stated that Belgium resembles an international organization.

\footnotetext{
${ }^{4}$ An exception is the mobility tax (Bollen et al. 2006: 157). Yet in general, the imbalance between the large spending autonomy and restricted taxation powers is often the number one obstacle in intergovernmental cooperation on concrete issues (Niestroy 2005: 100). It is also at the core of the current political stalemate since the 2010 federal elections.
} 
Among the other instruments of intergovernmental relations, the Deliberation Committee is the best known and most formal one (Reuchamps and Onclin 2009: 33). It is composed of the Prime Minister, five federal ministers and six subnational ministers (with a perfect equilibrium of Flemish and francophone representatives). When an issue is brought to the Deliberation Committee, the members have to find a solution within 60 days. It is the "compromise-building measure of last resort" (Swenden and Jans 2006: 887), only used in the most pressing situations when all other mechanisms have failed to settle a certain dispute. That is also why it is rarely used. Much more important in day-to-day politics are the interministerial conferences. Since 1992, those conferences bring together federal and subnational ministers of a certain policy area (e.g. Environment, Agriculture, Health). At the moment, 18 interministerial conferences are operational (Kanselarij van de Eerste Minister 2009). ${ }^{5}$ Each conference encloses a number of lower-level working groups for coordination on concrete policy issues. Besides intra-Belgian cooperation on sectoral matters, the interministerial conferences also deal with the international dimensions of those issues. That is because the many sectoral coordination efforts became too much to handle for the Foreign Ministry, which previously dealt with all of them (Beyers and Bursens 2006: 1065). Decision-making in all those cooperation bodies happens by unanimity only. As a consequence of the principle of no hierarchy, persuasion and voluntary cooperation are the only leverage for intergovernmental relations (Jans and Tombeur 2000: 144).

The de facto cooperative character of Belgian federalism is intensified by the 'Europeanization' of policies, which is explained in the next section.

\subsection{EUROPEANIZATION OF INTERGOVERNMENTAL RELATIONS}

In Belgium, a large part of the efforts towards intergovernmental cooperation is triggered by external requirements, such as European or global commitments (Beyers and Bursens 2006: 1058; Swenden and Jans 2006: 886). Indeed, in many cases international requirements (mostly EU-related) are the number one argument to bring the different levels of government around the same table. Without international requirements, it would be much harder to incite all governments to invest in intergovernmental cooperation. The reason is that many of the policy domains for which the subnational governments have important competences, are

\footnotetext{
${ }^{5}$ Besides those permanent interministerial conferences, conferences can be created on an ad hoc basis. An example was the 'Interministerial Conference for Sustainable Development ad hoc', set up in 2004 to negotiate on a national sustainable development strategy, but gone silent after the failure to move beyond a mere framework text (Happaerts 2010a: 20).
} 
those domains in which the EU has a large responsibility as well (Beyers and Bursens 2006: 1063). Typical examples are environment and agriculture (see, for instance, Beyers et al. 2004). The 'Europeanization' of policy domains thus brings along a Europeanization of intergovernmental cooperation in Belgium. Many of the mechanisms that characterize the cooperative form of federalism are indeed triggered by international developments. In numerous cases, such mechanisms are created in a first instance because the EU requires the output of a certain report or the adoption of a certain position. Previous research showed that almost $70 \%$ of the concluded cooperation agreements were developed because of international requirements (Jans and Tombeur 2000: 152). With regard to the external dimension of policies, those cooperation agreements often focus on the following issues: the development of a Belgian position in international negotiations, the representation of Belgium and the composition of the Belgian delegation in international negotiations, the dissemination of information, and dispute settlement (Van den Brande et al. 2011). An intervening factor in the Europeanization of intergovernmental relations is that the EU traditionally has a high normative authority in Belgium. What the EU says or does is rarely criticized or even questioned by Belgian politicians—unlike in many other EU member states. It is often easier for politicians to agree on EU requirements than to rely on intra-Belgian negotiations (Niestroy 2005: 77, 87). ${ }^{6}$

The Europeanization of intergovernmental relations in Belgium de facto weakens the autonomy of the subnational governments (Beyers and Bursens 2006: 1058, 1063). Although they probably have the highest degree of autonomy of all subnational governments in Europe, certainly with regard to international decisionmaking, they are to a large extent confined to intergovernmental relations if they want to exert that autonomy. In many cases, the federal government is the coordinating partner in those intergovernmental relations. That is mostly true when external relations are concerned, since the federal government remains the main contact point for international organizations.

\subsection{EXECUTIVE FEDERALISM AND POLITICIZED RELATIONS}

An important characteristic of the Belgian system is executive federalism (Swenden and Jans 2006: 886), which means that intergovernmental relations are controlled by elected officials of both levels of government-rather than, for instance, by

\footnotetext{
${ }^{6}$ A good example is the drafting of sustainable development strategies in Flanders and Wallonia. Instead of mounting a negotiation or consultation phase to decide on which themes to consider, in both cases the themes of the EU Sustainable Development Strategy were simply copied (Happaerts 2010b: 6; Happaerts and Van den Brande 2010: 22).
} 
parliaments (Skogstad 2000: 57). Furthermore, Belgium is a highly politicized country (Niestroy 2005: 86), meaning that all major decisions are taken by political officials, at the expense of the administration. It is often labelled a 'particracy' (Peters 2006: 1081), because policy and decision-making are monopolized by the political parties. That is also true for intergovernmental relations. Ministerial cabinets, the personal advisor of each federal and subnational minister, are traditionally the main actors in Belgian policy-making (Brans et al. 2005: 218), and they are omnipresent in all intergovernmental cooperation mechanisms. Because until 2004 the federal government and all subnational governments were controlled by the same coalitions, that meant that intergovernmental relations were to a large degree 'intra-party' relations (Swenden and Jans 2006: 886). The political symmetry until 2004 thus highly facilitated intergovernmental relations (cf Keating and McEwen 2005: 417). It also favoured the policy coherence among levels of government and, more generally, it eased Belgium's gradual transition towards an ever more federalized country (Reuchamps and Onclin 2009: 26). When intergovernmental tensions did arise, the federal government coalition was usually the forum where they were resolved. Since unanimity is the rule in intergovernmental decision-making, the threat of political instability at one level of government was the common tool used by political parties to obtain a consensus at the other level or within intergovernmental forums.

That situation changed drastically in 2004. After the subnational elections of that year, coalitions were installed at the subnational level that for the first time did not parallel the ruling coalition at the federal level. Since then, several political parties have been in power at one level of government, and in opposition at the other level. ${ }^{7}$ Parties in that situation are less willing to 'save' the stability of a government of which they form no part. That political incongruence gravely complicates intergovernmental relations in general and the resolution of intergovernmental conflicts in particular (Swenden and Jans 2006: 887).

\footnotetext{
${ }^{7}$ For instance, since July 2009 Flanders is governed by a coalition of Christian Democrats, Socialists and Flemish nationalists. In Wallonia, a government of Socialists, Greens and Christian Democrats was set up. The Flemish and francophone Liberals are thus in the opposition in Flanders and Wallonia-in Flanders for the first time in ten years-while they are still in power at the federal level (where no new government has been formed since the June 2010 elections). Inversely, the Flemish socialists have been in the opposition at the federal level since 2007, while they have continuously been in power in Flanders since 1988.
} 


\section{INTERGOVERNMENTAL RELATIONS ON DOMESTIC CLIMATE CHANGE POLICY IN BELGIUM}

This section investigates how Belgian federalism shapes intergovernmental relations with regard to the country's climate change policy. To examine this, we analyse three key decision-making processes. We first discuss the intra-Belgian burden sharing agreement (3.1). Subsequently, we turn to the national climate change policy (3.2), before briefly discussing the policies of the individual entities (3.3).

\subsection{NEGOTIATING A BURDEN SHARING AGREEMENT}

At the global level, the EU committed to an $8 \%$ reduction of greenhouse gas (GHG) emissions compared to 1990 levels in the 1997 Kyoto Protocol, of which the first commitment period runs from 2008 to 2012. Within the EU, a burden sharing agreement was subsequently negotiated in 1998 and formalized in 2002 by a Council decision. ${ }^{8}$ That Council decision assigned Belgium a reduction obligation of $7.5 \%$. Since GHG emission reductions touch upon the competences of both the federal government and the three Regions, and because of the specific character of Belgian federalism, the national target had to be subdivided among four entities. The negotiations to that effect were very similar to those that had taken place at the global and EU levels.

The first action undertaken was to create an institutional framework for conducting those talks and other negotiations related to climate change policy. In November 2002, a few months after Belgium had ratified the Kyoto Protocol (Belgisch Staatsblad 2002), the federal and subnational governments concluded their first cooperation agreement on climate change (Belgisch Staatsblad 2003b). That agreement established the National Climate Commission, a typically Belgian coordination forum composed of sixteen members, four representatives ${ }^{9}$ from each contracting party (the federal government, Flanders, Wallonia and Brussels). Although it is formally an independent organ, the National Climate Commission has close ties with one of the 18 interministerial conferences, the Interministerial Conference on the Environment (IMCE). It has to advise the IMCE on a National Climate Plan (cf 3.2), and it is the IMCE which settles conflicts within the National

\footnotetext{
${ }^{8}$ The preliminary, political agreement reached by the Environment ministers of the EU-15 in 1998 was formalized by an April 2002 Council decision on internal burden sharing (Council of the EU 2002). That decision paved the way for the European Community's ratification of the Protocol.

${ }^{9}$ Those four representatives in principle represent the four most relevant ministerial cabinets of each government. After the initial enthusiasm, the meetings of the National Climate Commission became less frequent, and now only the Environment and Energy cabinets provide an active follow-up.
} 
Climate Commission and which has to evaluate the intergovernmental cooperation on climate change. When it discusses climate change, the IMCE-normally composed of the federal and subnational Environment ministers only-is extended with the federal and subnational Prime Ministers, with the federal Budget minister, with the subnational Economy ministers, and with all ministers responsible for Energy, Transport, Taxes and Development Cooperation (Bollen et al. 2006: 159). The 'extended' IMCE is assisted by the National Climate Commission with regard to Belgian climate change policy (cf 3.2). For the coordination of a Belgian position in international climate change policy, the IMCE has a specific working group, the Coordination Committee for International Environment Policy (cf 4.1). This decisionmaking structure is visualized in Figure 1.

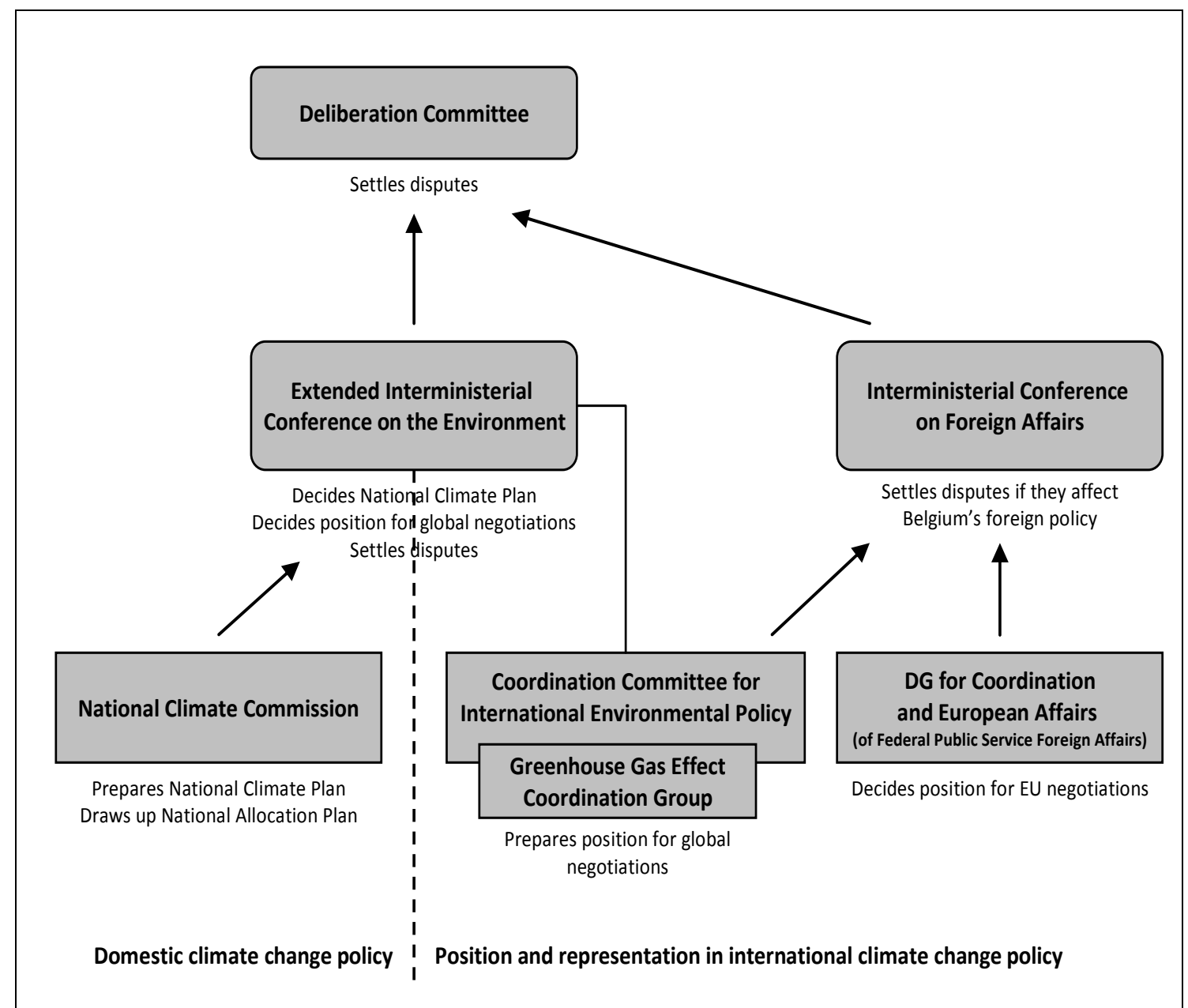

Figure 1 Intergovernmental relations and decision-making on climate change policy in Belgium

Since it took a long time between the start of the negotiations on the cooperation agreement and the eventual establishment of the National Climate Commission, the talks on the intra-Belgian burden sharing agreement took place in ad hoc 
administrative and inter-cabinet working groups, and eventually within the IMCE itself. The approach used in the talks has been characterized as a "best of both worlds' scenario (Bollen et al. 2006: 165), meaning that each Region would advance the target it wanted to commit to, and that the federal government would support reductions with policy measures related to its competences and by applying flexible mechanisms. Yet the governments did not agree on a common position within the IMCE, inter alia because of the 2003 federal elections, and the matter was referred to the Deliberation Committee.

Prime Minister Verhofstadt finally announced an agreement on 8 March 2004 (FOD VVVL 2009). Flanders committed to a reduction of $5.2 \%$, Wallonia pledged to reduce $7.5 \%$ and Brussels could increase its emissions with $3.475 \%$. One of the difficulties during the negotiations was the hard stance of the Flemish government, which insisted that more reductions should be made in those Regions where they would be most efficient. Flanders pointed towards its own energy-intensive industry (e.g. the chemical industry), suggesting that reductions would be economically more efficient in Wallonia. Wallonia had relatively high emissions in 1990-Kyoto's base year-when the heavy coal industry was still operational, and had actually reduced its emissions by the end of the decade because of the decline of those activities (Van Hecke and Zgajewski 2008: 8). During the negotiations, however, Wallonia continuously urged for identical targets for each Region (Bollen et al. 2006: 165). Also Brussels kept a firm stance, insisting that it would be economically inefficient for it to reduce emissions. However, according to Van Hecke and Zgajewski (2008: 26), its eventual permission to slightly increase its emissions with regard to 1990 shows the relative insignificance of the emissions in the small and de-industrialized Capital Region. As the sum of the three Regions' proposed targets did not result in the $7.5 \%$ Belgian target under the EU's burden sharing agreement, the federal government committed to additional measures to reduce $4.8 \mathrm{Mt} \mathrm{CO}_{2}$-equivalents per year, and to the purchase of carbon credits equivalent to $2.46 \mathrm{Mt}$ per year through the Kyoto Protocol's flexible mechanisms (such as the Clean Development Mechanism, $\mathrm{CDM}^{10}$ ) (Bollen et al. 2006: 166).

With the end of Kyoto's first commitment period approaching, negotiations have been started on a second intra-Belgian burden sharing agreement. That is the consequence of the EU's climate and energy package, agreed in December 2008

\footnotetext{
${ }^{10}$ The CDM was created through Article 12 of the Kyoto Protocol. It allows industrialized 'Annex I' countries to undertake emission reduction projects in developing countries. The 'certified emission reductions' achieved through such project activities can be counted toward the fulfillment of the Annex I party's reduction target.
} 
(the so-called '20-20-20' targets $^{11}$ ). Under that agreement and the subsequent internal 'effort sharing' deal concluded within the EU (Vogler 2009), Belgium needs to reduce its GHG emissions in the so-called non-ETS-sectors ${ }^{12}$ by $15 \%$ by $2020 .{ }^{13}$ The negotiations on the intra-Belgian distribution of that target are led by the National Climate Commission, and were started in an administrative working group in which the Federal Planning Bureau played a leading role. The Planning Bureau delivered a report to the National Climate Commission on possible scenarios to distribute the target among the different governments (Henry and Gouzée 2009). The National Climate Commission then decided to refer the negotiations to an intercabinet working group, so that political officials could decide on which scenario to use. Yet since the June 2010 federal elections, the issue has been completely frozen. It remains to be seen when the talks will be restarted, as at the time of writing, Belgium is still in a political stalemate following those elections. In any case, the positions of the different parties are different compared to those on the first burden sharing agreement, as it now concerns non-ETS sectors only. For that reason, the negotiations do not concern industrial installations, but rather sectors such as housing and transport. Differences between the actors are now mostly related to party political positions. The Walloon government, for instance, is promoting ambitious targets due to the important position of the Green party in the government coalition. ${ }^{14}$ In Flanders, where the Environment portfolio has been held by the Christian Democrats since 2004, the ambitions are remarkably lower. ${ }^{15} \mathrm{An}$ added difficulty is that since 2009, the Flemish government wants to use all of its competences to a maximal degree in all areas (Vlaamse Regering 2009: 10). That could imply that in the second burden sharing agreement, the federal government would have no more role to play. The negotiations thus promise to be difficult and slow, especially in the current political climate.

\footnotetext{
${ }^{11}$ By 2020, the EU aims to reduce GHG emissions by $20 \%$ (by $30 \%$ if a global agreement including comparable targets for other industrialized countries is reached), to reduce energy consumption by $20 \%$ and to achieve $20 \%$ of renewable energy (European Council 2007).

${ }_{12}$ For the period 2013-2020, the ETS (European Emissions Trading System) stipulates a reduction of emissions by $21 \%$ compared to 2005 levels in the covered sectors (industrial installations). The emissions not covered by the ETS, i.e. those stemming from the transportation, buildings or waste sector, were subject to a new internal deal on 'effort sharing', which attributes the 27 member states the remaining necessary reduction obligations to achieve the overall EU $20 \%$ reductions.

${ }^{13}$ Belgium also needs to include $13 \%$ of renewable energy in its final energy consumption. Negotiations on the distribution of that target have been held in the framework of the intra-Belgian cooperation mechanisms on energy, which are not further developed in this paper.

${ }^{14}$ The 2009 subnational elections produced a phenomenal victory for the Green party, who moved from 8.5 to $18.5 \%$ in Wallonia. The Greens were thus in a strong bargaining position, which resulted in a coalition agreement containing ambitious goals for sustainable development, energy and climate change policy (Happaerts 2010b: 10).

${ }^{15}$ For instance, Flanders states that in "the further interpretation of the climate policy, it will be made sure that Flanders, both in the European and in the Belgian context, does not have to carry an excessive burden" (Vlaamse Overheid 2006: 34, personal translation).
} 
The repeated rounds of negotiations on a burden sharing agreement in the climate change domain provide us with many insights into the link between Belgian federalism and intergovernmental relations. First, decision-making on internal climate change policy represents a perfect illustration of the Europeanization of intergovernmental relations. Cooperation between the federal and subnational governments on climate change did not occur before the conclusion of an EU agreement-which constitutes in itself the result of a global agreement-requiring action by the member states. Similarly, the EU is the main driver of intra-Belgian cooperation on environmental issues in general. Second, the conclusion of a national agreement can only rely on voluntary cooperation. Even in the case of legally binding EU commitments, the federal government cannot impose anything on the subnational governments. The principle of no hierarchy implies furthermore that intra-Belgian cooperation highly resembles international negotiations. Third, the discussion on the burden sharing agreement displays the use of the typical mechanisms of intergovernmental cooperation. The arrangements are anchored in a cooperation agreement, and relations take place within an intergovernmental institution related to one of the interministerial conferences. In addition, climate change appears to be one of those rare pressing issues for which the final consensus-building of the Deliberation Committee is needed. That illustrates that it is a very sensitive issue, and one in which the different levels cannot simply be persuaded to change their point of view through the 'day-to-day' cooperation mechanisms. A fourth and final point relates to another typical feature of Belgian federalism only implicitly touched upon in the conceptual framework this paper operates with. The federal government not only plays the difficult role of a coordinating partner in intergovernmental relations, but oftentimes it is also the one who pays the bill to resolve complex disagreements between the Regions. In the case of climate change, it needed to fill the gap with specific federal reduction measures, but also through the use of costly flexible mechanisms.

\subsection{FORGING A NATIONAL ACTION PLAN}

As specific GHG emission reduction targets have been allocated to the federal level and to the three Regions, all governments conduct a climate change policy within their own scope of competences. ${ }^{16}$ That means that there is no common 'national'

\footnotetext{
${ }^{16}$ The different levels of governance had already taken some measures to tackle climate change before the conclusion of the burden sharing agreement. For a brief historical overview, see Bollen et al. (2006: 72-84).
} 
climate change policy. However, because of international reporting duties, it is desirable to present some sort of joint national policy plan. In 2002, on the same day the cooperation agreement was concluded, the governments approved the first National Climate Plan 2002-2012. That Plan was prepared by the extended IMCE, with some delay due to disagreements between the governments on a temporary stabilization of GHG emissions by 2005 (Bollen et al. 2006: 78). Future National Climate Plans were to be prepared by the National Climate Commission and approved by the IMCE (Belgisch Staatsblad 2003b: §6). That happened already in 2009, when the second National Climate Plan 2009-2012 was endorsed (NKC 2009). The Plan does not announce new policy measures, but should rather be considered as an inventory of the existing policy initiatives of the federal and subnational governments, categorized according to policy domains.

With regard to emissions trading, the implementation of the ETS is the responsibility of the Regions. They are in charge of the distribution of $\mathrm{CO}_{2}$ allowances among the installations in their own territory (Van Hecke and Zgajewski 2008: 9), which is a logical consequence of their exclusive competences in industrial and economic policies. Yet the ETS obliges every member state to have one national registry, a database that keeps track of all emissions and emission allowances in that country. The obligation to have a 'national' structure also brings the federal government into the picture. The different levels therefore needed to conclude a cooperation agreement. That was done in 2005, giving the coordinating responsibility for the national registry to the federal Environment minister (Belgisch Staatsblad 2005). ${ }^{17}$ The EU also obliges member states to submit a National Allocation Plan (NAP) on the distribution of its emission allowances to the European Commission. In Belgium, the three Regions each have to draw up their own allocation plans. Those are approved by the National Climate Commission, which subsequently assembles them into a single Belgian NAP, which is sent to the European Commission for approval (Van Hecke and Zgajewski 2008: 9). An awkward situation arose when the latter rejected Belgium's proposed NAP for the second commitment period of the ETS (2008-2012). The NAP advanced a yearly amount of emissions of $63.3 \mathrm{Mt} \mathrm{CO}_{2}^{-}$ equivalents, while the European Commission only allowed 58.5 Mt. Difficult intraBelgian negotiations followed-during the long period of political instability after the 2007 federal elections-to distribute the 'additional' reductions. ${ }^{18}$ An agreement was

\footnotetext{
17 That cooperation agreement was altered by a second cooperation agreement on the national registry in 2008 (Belgisch Staatsblad 2008b).

${ }_{18}$ The negotiations were not facilitated by ArcelorMittal's announcement to re-launch a plant in Wallonia (Seraing), for which it requested additional allowances (Van Hecke and Zgajewski 2008: 23). ArcelorMittal, the world's largest steel producer and one of the EU's most significant GHG emitters, occupies a prominent place in Wallonia's industrial history and is still an important employer in the Region.
} 
eventually concluded in 2008 , stating that the additional reductions would be equally divided between Flanders and Wallonia (Van Hecke and Zgajewski 2008: 10).

Also with regard to the other Kyoto flexible mechanisms, the Clean Development Mechanism and Joint Implementation (JI), arrangements had to be made among the different levels. A cooperation agreement was concluded in February 2007. To comply with the obligations under the Kyoto Protocol, the agreement appoints the National Climate Commission as the 'designated national authority' for CDM and as the 'designated focal point' for Jl. It also stipulates which types of projects fall under federal or subnational authority, and under which conditions (Belgisch Staatsblad 2008a).

In conclusion, the case of climate change illustrates how there is no such thing as a national policy in Belgium. Remarkably, if something carrying the label 'national' is launched, it is almost always the result of an effort to comply with international commitments. Drawing up such a national plan usually means not much more than the sum of federal and subnational measures in the policy area in question. Another observation that can be drawn from the discussion is that intergovernmental coordination is often immobilized by upcoming elections (whether federal or subnational). Moreover, talks are regularly not resumed during periods of political instability following elections (as illustrated by the post-electoral problems both in 2007 and 2010). As a consequence, important issues that require intra-Belgian intergovernmental negotiations are often blocked for many months in an election year. That trend can be very problematic in a country that has held six elections in the past eleven years-that is not counting the municipal and provincial elections!

\subsection{FEDERAL AND SUBNATIONAL CLIMATE CHANGE POLICIES}

Since the national climate change policy is the sum of the federal and the subnational policies, this section gives a brief overview of those policies. Although they are not subject to intergovernmental relations, it is pertinent to verify whether the characteristics of Belgian federalism result in diverging policies, which, in turn, can reinforce certain trends impacting (negatively) on the conduct of intergovernmental relations.

At the federal level, the initiatives to reduce GHG emissions focus on the production of off-shore wind energy, on taxation tools to promote clean transport and biofuels, on tax cuts for energy efficient buildings and on the promotion of sustainable 
consumption through energy labels, among other things. ${ }^{19}$ To reach the Belgian emission target, the federal government also needs to purchase a significant amount of carbon credits through flexible mechanisms (CDM and $\mathrm{JI}$ ). Yet, the federal CDM/JI policy has suffered from a range of difficulties. For instance, the federal government imposes additional criteria to CDM/JI projects, which makes the approval process more complex (Conix 2009: 60). Projects are also unattractive for investors because the different levels in Belgium all have their own specific procedures, which implies that the Belgian CDM/JI policy is very fragmented (Conix 2009: 70). Moreover, due to all the above-mentioned intergovernmental problems, and the fact that the cooperation agreement on flexible mechanisms was concluded only in 2007 , the federal policy regarding CDM and $\mathrm{JI}$ started with significant delay compared to neighbouring countries (Conix 2009: 71-72). Finally, Conix (2009: 71) found that the different levels in Belgium often want to cooperate with each other at administrative level, but have to be careful to do so when their ministers are from different political parties. In those cases, apparently, cooperation between the administrations is not full-heartedly supported by ministers.

Turning now to the subnational level, in Wallonia and Brussels climate change is tackled in combination with air quality. In Flanders, it is a separate planning process. The Flemish climate change policy focuses on renewable energy, rational energy use in buildings, some stimulating measures in the transport sector, and sustainable agriculture and forestry, among other things (Vlaamse Overheid 2006). In addition, $20 \%$ of the Flemish reductions will be achieved through the use of flexible mechanisms, both through the investment in primary projects as through purchases on the secondary carbon market (Van Hecke and Zgajewski 2008: 19). Wallonia also takes measures in the sectors of transport, energy, agriculture and forests. However, since its policy combines climate with air quality, the scope of its measures is broader and also targets spatial planning, waste and biodiversity (Ministère de la Région wallonne 2008). The policy of the Brussels Region focuses on transport, on energy use in residential and service buildings and on industry. Yet, the measures taken in the industry only focus on air quality, not on GHG emissions. Brussels emphasizes that the industrial measures must "not distort the proportions between Regions" (Brussels Hoofdstedelijk Gewest 2002: 61, personal translation), suggesting that the economic importance of the capital should not be hindered by imposing strict measures on the Brussels-based industry. $30 \%$ of the effort in Brussels relies on the purchase of credits through a carbon fund (Van Hecke and Zgajewski 2008: 28). It must be emphasized that the three subnational climate

\footnotetext{
${ }^{19}$ Many of those measures were announced after a special government meeting in Raversijde in March 2004 (FOD VVVL 2008a).
} 
policies are currently based on the Regions' obligations under the 2004 burden sharing agreement. At the time of writing, preparations for new plans should be ongoing, but the governments are still faced with uncertainty about their targets for 2020 (cf 3.1).

In conclusion, it is clear that Belgian federalism, given the distribution of competences, favours diverging climate change policies at different levels, and also allows for differences among the subnational governments. According to their own political preferences, all four governments have climate change plans aimed at different sectors, with varying instruments and covering different periods. Furthermore, the brief analysis of the different policies shows that many of the federal initiatives focus on tax measures, while the subnational governments' possibilities are very limited in that domain, due to their limited taxation competences. As a result of the divergence, coordination and synergy between the governments becomes even more difficult.

\section{INTERGOVERNMENTAL RELATIONS ON THE BELGIAN POSITION AND REPRESENTATION IN INTERNATIONAL DECISION-MAKING ON CLIMATE CHANGE}

So far, this contribution has looked into how the key characteristics of Belgian federalism play out in the intergovernmental relations regarding the decision-making on domestic climate change policies in Belgium. This section of the paper examines the external dimension of the country's climate change policy. As a global commons problem, climate change is being tackled at all levels of global governance, the most important ones beyond the realm of the state being the EU and the United Nations (UN) climate regime. ${ }^{20}$ The analysis focuses on the intergovernmental relations regarding the decision-making processes leading to the definition of a common Belgian position in both the EU and the global climate negotiations (4.1), and on those leading to the representation of that position (4.2). Finally, the 'extra-state' routes subnational governments use to assure additional presence on the international scene are briefly explored to verify their impact on intergovernmental relations (4.3).

\footnotetext{
${ }^{20}$ The global climate regime developed around the 1992 UN Framework Convention on Climate Change (UNFCCC) and its 1997 Kyoto Protocol. Since late 2007, parties are negotiating a reform of the regime for the period after 2012, when the first commitment period of the Kyoto Protocol expires.
} 


\subsection{DEFINING A BELGIAN POSITION FOR EU AND GLOBAL NEGOTIATIONS ON CLIMATE CHANGE}

The EU arguably is the key arena for climate change policy-making of its member states. With its 2008 'climate and energy package' of legislative measures, the Union managed to lift its policies to a new level of harmonization (Van Schaik 2010). By consequence, the majority of climate measures in vigour in the EU's member states effectively represent the transposition of EU law. The member states thus have a clear incentive to define their climate policies in line with the intra-EU debates about this topic. At the same time, the dividing line between EU internal and external climate change policies is very thin: what the Union does internally has repercussions for its international negotiation position, and vice-versa (Oberthür 2009). Oftentimes, internal policies on climate change in the EU are even designed with the purpose of impacting on the international debates (Schunz 2010).21 As a result, climate change is one of the few foreign policy issues on which the EU defends a-at least in its key contours-largely common position vis-à-vis the wider world. That intertwinement between internal and external EU climate change policies has two implications for national decision-making on this issue in Belgium: firstly, Belgium needs to strive for defining coherent positions for both the EU and the international negotiation contexts; secondly, as a comparatively smaller member state, Belgium will by and large strive to impact on the EU's internal and external policies rather than pursuing an additional, extra-EU strategy to make its voice heard in the global negotiations. That means that it will attempt to impact on the EU's policy positions at the three key levels of climate policy-making: the preparatory meetings at the administrative level, the Environment Council and the European Council, before and during the international negotiations on climate change. This section focuses on the intergovernmental relations regarding intra-Belgian decision-making of policy positions on climate change with regard to the most recent and ongoing talks on a post-2012 climate regime at the EU and global level.

Formally, a key role in the decision-making on a Belgian position for the EU and global negotiations on climate change is, as for internal decision-making on these issues, played by the IMCE (Jans and Tombeur 2000: 160) (see Figure 1). As the IMCE meets only a few times per year, a 1995 cooperation agreement determines which bodies prepare and follow-up on the EU and international climate policies on a more regular basis (Belgisch Staatsblad 1995).

\footnotetext{
${ }^{21}$ Inversely, the EU is itself subject to pressures from the international negotiations (Costa 2009), which are not so dissimilar from the pressures that often force the Belgian entities to cooperate.
} 
For the global negotiations, the decisions of the IMCE are prepared by the Coordination Committee for International Environmental Policy (CCIEP), composed of officials from the various Environment departments of the federal and subnational administrations (NKC 2009: 22). The CCIEP is served by several working groups. For climate change specifically, the Greenhouse Gas Effect Coordination Group (GHGECG) is responsible for coordinating the Belgian positions (Lavrysen 2010: 1314; NKC 2009: 22). It drafts strategic and legislative documents as well as recommendations for the CCIEP. ${ }^{22}$ The secretariat of the GHGECG is hosted by the climate change section of the federal Environment Ministry (NKC 2009: 22). That section also serves as the 'national focal point' for the UNFCCC, and its head of unit acts as the so-called Belgian 'pilot' ${ }^{23}$ for all external climate change issues. Both the IMCE and the CCIEP take their decisions by consensus (NKC 2009: 22).

In the 1995 cooperation agreement on international environmental policy, the CCIEP is explicitly not mandated for defining positions for internal EU negotiations (Belgisch Staatsblad 1995: §1.1). For EU policies, preparation and follow-up is the responsibility of the Directorate-General for Coordination and European Affairs (DGE) of the federal Foreign Ministry (Jans and Tombeur 2000: 160; Lavrysen 2010: 13-14). This unit coordinates and ultimately approves the Belgian positions defended in the Environment Council (NKC 2009). ${ }^{24}$

The relationship between the different bodies as well as the roles of the pilot and of the different experts in the working groups are further specified in a 2004 vademecum, a political accord concluded by the IMCE after the experience with the 2001 EU Presidency (CCIM 2004). Given the specific multi-level nature of global climate governance, networks have been established between the different bodies to coordinate positions defended in the EU and global negotiation contexts.

In practice, the intergovernmental relations, also based on these networks, function more smoothly at the administrative level than at the political level, where final decisions on the Belgian positions are taken. For more technical issues, that is often not very problematic. Complications regularly arise, however, regarding issues of

\footnotetext{
${ }^{22}$ The GHGECG is itself composed of several ( $a d$ hoc) working groups, inter alia on 'Future Action'. That group is concerned with the preparation of Belgian positions on the shape of post-2012 international climate policies (NKC 2009: 22).

${ }^{23} \mathrm{~A}$ pilot is a federal or subnational official who is made responsible for the internal Belgian supervision of an individual dossier in multilateral negotiations (Van den Brande et al. 2011). The federal official who acts as Belgian pilot for the external climate change issues is assisted in his functions by a co-pilot from the federal Foreign Ministry and a co-pilot from the Flemish Environment Ministry.

${ }^{24}$ Since the coordination by DGE comes under the federal Foreign Ministry, the settlement of disputes within DGE is done by the Interministerial Conference on Foreign Affairs (Belgisch Staatsblad 1994: §). If disputes arise in the CCIEP and affect Belgium's foreign policy, they are also referred to the Interministerial Conference on Foreign Affairs (Belgisch Staatsblad 1995: §7.1). All other disputes that arise in the CCIEP are referred to the IMCE (see Figure 1).
} 
greater political interest, not infrequent in the context of a topic such as climate change. Here, (party) political differences as well as personal animosities between politicians of the different governments play a role.

A significant recent example of the type of problematic decision-making process that can arise, was the Belgian stance on the target proposal the EU was going to advance in the post-2012 regime negotiations. Since 2007, the EU had approached the global talks with a unilateral $20 \%$ emission reduction proposal by 2020 , and an offer to move to $30 \%$, if other developed countries adopted similar reductions (European Council 2007). That position had also been supported by Belgium. Towards the finale of the Conference of the Parties (COP) in Copenhagen in December 2009, several EU member states, among them the UK and France, wanted the EU to boost its position in order to give an impetus to the stalled talks. They proposed to transform the conditional offer of $30 \%$ reductions into an unconditional one. Within the Belgian delegation, the necessity to take a stance on that key item of the EU's overall negotiation position stirred a heated debate among the four Environment Ministers present in Copenhagen (federal Minister Magnette, Flemish Minister Schauvliege, Walloon Minister Henry and Brussels Minister Huytebroeck), who apparently had little common ground in their positions regarding the approach to those negotiations. Not surprisingly, they also had very different views on the general strategy Belgium should suggest the EU to pursue, to avoid failure of the summit. The Christian Democrat Flemish Minister supported the 2007 EU position, while her counterparts from the francophone Socialist party (federal government) and from the francophone Greens (Wallonia, Brussels) spoke in favour of the more ambitious unilateral $30 \%$ proposal. In the absence of a compromise, Belgium could not adopt a clear position (see also Van den Brande et al. 2011), and Prime Minister Leterme, himself a Flemish Christian Democrat, had to support the status quo during the informal European Council meeting organized on the last day of negotiations in Copenhagen. ${ }^{25}$

What do those institutional and political realities regarding decision-making on Belgian external climate change policy tell us about the intergovernmental relations in this domain?

Most importantly, intra-Belgian decision-making on external climate change as a highly sensitive issue is again regulated by several cooperation agreements and

\footnotetext{
${ }^{25}$ As countries like Germany, Italy and Poland also argued for the status quo, the proposal by the more progressive countries of adopting $30 \%$ unilateral reductions was effectively discarded. In 2010 , this discussion has been pursued, but without results. A decision has been postponed several times and was effectively shifted to the 2011 Spring European Council so that the topic is not bound to interfere with EU—or Belgian-external climate change policy at the COP in Cancun.
} 
accords creating numerous bodies. The latter do represent efforts to regulate intergovernmental relations and make them run more smoothly in practice, but the fact that decisions ultimately have to be taken by consensus at the highest political level offsets potential efficiency gains.

In that regard, two other features of Belgian federalism play out. On the one hand, decisions are strongly shaped by the political tensions that are characteristic of Belgian intergovernmental relations and a direct consequence of the country's federal system. The Belgium-specific form of 'divided government', with ministers from conservative and progressive parties at different levels having to forge compromises, makes it highly difficult to come up with a common position on a sensitive topic such as climate change. That regularly results in status quo policies: if no consensus is found, no changes are enacted. Moreover, it makes it difficult for Belgium to play a proactive role. On the other hand, decisions are only taken when the pressure from the EU and/or global level is significant, confirming also here a sort of Europeanization trend. In that respect, it is interesting to note that Belgium functions very much like the EU-27 itself, which also regularly uses the pressure from the outside to forge internal package deals, not the least in the climate change domain.

\subsection{REPRESENTING THE BELGIAN POSITION IN EU AND GLOBAL NEGOTIATIONS ON CLIMATE CHANGE}

Just as the definition of its external climate change policy positions is geared primarily towards the EU context, for the reasons outlined in the preceding section, the key arena for the representation of its positions is the EU, both regarding policies that Belgium wants the EU to adopt internally and those it wants it to defend internationally. Like all parties to the UNFCCC, Belgium does send a national delegation to the global climate negotiations, whose members are free to interact with other parties' delegates. ${ }^{26}$ De facto, however, Belgium's representation is first and foremost assured through the EU.

When it comes to discussing the Belgian representation within the EU, three layers of policy-making need to be distinguished. The main environmental decision-making body in the EU is the Environment Council, and Belgium's participation in the Council is formally regulated in a 1994 cooperation agreement, updated in 2003 (Belgisch Staatsblad 1994, 2003a). Since most environmental matters are an exclusive

\footnotetext{
${ }^{26}$ Competences on environmental policy are shared in the EU so that both the EU and the member states are contracting parties to the UNFCCC and the Kyoto Protocol.
} 
Regional competence, Belgium is represented in the Council by a Regional Environment minister, accompanied by a so-called 'federal assessor' (i.e. the federal Environment minister). A six-month rotation system was created to assure that the Flemish, Walloon and Brussels ministers all get to serve their term in the Council. Decisions of the Environment Council (on both internal and external EU climate policies) are prepared in a complex Working Party structure that reports to the EU's Committee of Permanent Representatives. In this second layer of EU internal and external climate policy-making, Belgium is primarily represented through diplomats and experts from the federal government. Thirdly, given the political sensitivity of the topic of climate change, the European Council has, since the mid-2000s, regularly served as the final political instance for endorsing EU climate change policies. Here, Belgium is represented by its head of government, the Prime Minister, who will normally defend the same positions that his colleagues, the federal and Regional Environment ministers, defended in the Environment Council.

For the duration of the Belgian EU Council Presidency in the second half of 2010, a special arrangement for the rotation system was negotiated. It was agreed that the Flemish Environment Minister presided the Environment Council, while the federal government, in this case Environment Minister Magnette of the care-taker government, occupied the Belgian seat. Therefore, while Flanders spoke for Belgium as the EU Presidency, the federal government spoke for Belgium as an EU member state.

Where decision-making on representation issues has thus been highly institutionalized within the EU, also as a result of the growing importance of the latter, this is to a lesser extent the case for its representation at the international level. As a result, intergovernmental relations on this topic can become problematic. Belgium's national delegation for the COP to the UNFCCC is composed by the IMCE, which also determines who speaks on behalf of Belgium (Belgisch Staatsblad 1995: §1.2). A long tradition of transparency implies that the delegation frequently includes a range of non-governmental stakeholders and the Environment ministers of all four governments. Four Ministers were thus present in both Copenhagen and Cancun. Despite the rotation agreement, there are no clear rules about the practical task-sharing between those players during summits. Not surprisingly, a conflict arose only days before the 2010 COP in Cancun, about who was to be the formal head of the Belgian delegation, federal Environment Minister Magnette (who spoke for Belgium as a member state) or Flemish Environment Minister Schauvliege (who presided the Environment Council and thus spoke on behalf of the EU at the summit) 
(Debusschere 2010). ${ }^{27}$ While heading a delegation implies mostly symbolic rights, such as speaking in the closing ceremony on behalf of one's country ${ }^{28}$, this conflict demonstrates the continued highly politicized atmosphere within the Belgian delegation, which was already visible in the run-up to and during the much more mediatized Copenhagen summit. Instead of a formal solution, the actors declared to the press, right before taking off to Cancun, to engage in pragmatic ad hoc tasksharing during the summit (De Morgen 2010).

In conclusion, decision-making on who is to speak on behalf of Belgium in EU bodies is strongly institutionalized. The arrangements are partially the result of experiences with holding the EU Council Presidency in 2001. It is thus again an expression of the Europeanization effect identified throughout this paper. At the same time, the designation of representatives for international conferences is also institutionalized, but can and does give rise to struggles among elected representatives from the different governments. Even if Belgian federalism incites the creation of cooperation agreements to attenuate such conflicts, such accords are unable to fully overcome the entrenched positions resulting from fundamental differences between the key political players at different levels of government.

\subsection{SUBNATIONAL GOVERNMENTS ON THE INTERNATIONAL SCENE}

Besides their strong international presence in Belgian and EU delegations, the subnational governments also use other mechanisms to be visible in the international debate, something the Belgian federal framework fully allows for.

As a matter of fact, beside their exceptional opportunities to use 'intra-state' routes, they also apply 'extra-state' routes for an international presence, for instance through their membership in transnational networks of subnational governments (Van den Brande et al. 2011). Such networks assembling subnational governments of different countries have been created on a wide range of topics, including in the environmental domain. They initially sprouted in an EU context, but more recently networks with a global scope have also been established (Happaerts et al. 2010b). Happaerts et al. (2010b) show that transnational networks of subnational

\footnotetext{
${ }^{27}$ Assuming the responsibility of an EU presidency formally implies that Minister Schauvliege represents an EU institution and not Belgium as a country. Within the EU, also during coordination meetings at Cancun, the Belgian position is represented by the federal assessor.

${ }^{28}$ Other than that, Belgium traditionally does not pursue significant contacts with other parties outside the EU route.
} 
governments have both an external and an internal dimension. On the one hand, they strive to represent their members in multilateral decision-making, thus reinforcing the voice and position of subnational governments. On the other hand, they aim to promote information-sharing and cooperation between their members, in part to help them implement international policies.

Flanders and Wallonia ${ }^{29}$ are members of the Network of Regional Governments for Sustainable Development (nrg4SD), which focuses part of its activities on the COP of the UNFCCC (Happaerts et al. 2010a: 134). They also participate in The Climate Group's States and Regions Alliance, which organizes events in the framework of the UNFCCC, such as the Climate Leaders Summit. ${ }^{30}$ The Belgian subnational governments mostly use such transnational networks for their internal dimension (i.e. for information-sharing and cooperation with their peers), since they have much more opportunities through intra-state routes to influence international decision-making. Nevertheless, they attach importance-especially in the Flemish case- to the fact that they have a direct international visibility via transnational networks, instead of being an 'invisible' part of the Belgian delegation (Happaerts et al. 2010b).

The characteristics of Belgian federalism impose no limitations whatsoever on the subnational governments to engage in independent activities on the international scene in matters that pertain to their own competences. Since such activities rarely have a concrete impact on their domestic policies (Happaerts et al. 2010a: 137), they do not arouse much interest from the federal government, and they do not impact intergovernmental relations on climate change policy. However, they can potentially complicate intra-Belgian efforts to speak with one voice at the international level.

\section{CONCLUSIONS}

In the conceptual framework of this paper, we highlighted three characteristics of Belgian federalism: the constitutionally 'dual' but de facto 'cooperative' federalism, the Europeanization of intergovernmental relations, and the politicization of relations. They have appeared to be strongly determining in intergovernmental relations on

\footnotetext{
${ }^{29}$ Brussels is not a member of transnational networks of subnational governments, because it mostly focuses on city networks, such as ICLEI or Metropolis.

${ }^{30}$ A similar new initiative is R20, which was launched by then Governor of California, Arnold Schwarzenegger (Office of the Governor 2009) following the perceived failure of the Copenhagen summit. Fashioned after the city network C40, R20 aims to assemble the subnational governments that are most progressive with regard to climate change policies. The Belgian subnational governments are not involved.
} 
climate change. In that regard, climate change is a highly suited case for the study of intergovernmental relations in Belgium, and it tells a great deal about the specificities and problems of the Belgian federal system.

With regard to the first characteristic, it is clear that intergovernmental relations on climate change policy are completely managed within the typical cooperation mechanisms of Belgian federalism. The governments have concluded a series of cooperation agreements to deal with different aspects of climate change policy, and coordination between the actors happens within a set of working groups that report to one of the interministerial conferences. The case of climate change thus illustrates the cooperative character of Belgian federalism. Even the Deliberation Committee has been invoked to cut the knot on a crucial issue. In those cooperation mechanisms, every decision is taken by consensus. Because of the principle of no hierarchy, the negotiations happen between equal partners. In Belgium, everything that is 'national' needs to be agreed by all levels, and besides voluntary cooperation there are no leverages to bring the governments to the negotiating table. Moreover, the principle of no hierarchy and the exclusivity of competences has allowed for diverging climate change policies of the federal and the three Regional governments (with regard to themes, instruments and deadlines of action plans). That divergence makes the already complex intergovernmental relations even more difficult. The Belgian federal system also places the federal government in an ambiguous position. With regard to climate change policy, it has very few relevant competences, but it is assigned an important coordination role because it is the only contact point for international organizations.

Secondly, intergovernmental relations on climate change policy in Belgium are highly Europeanized, meaning that many negotiations between the governments happen primarily to comply with EU requirements. Climate change policy relies on a complex dynamic of multi-level negotiations, where agreements continuously have to be forged at the global, European and Belgian level. Although the Europeanization of intergovernmental relations is very clear, the EU influence is not strong enough to overcome intra-Belgian stalemates. When internal political crises freeze intergovernmental relations on climate change policy, international requirements or EU-imposed deadlines are insufficient incentives to break domestic gridlocks. Furthermore, the Europeanized character of intergovernmental relations on climate change is illustrated by the fact that some important arrangements were negotiated after the experience of the 2001 Belgian EU Presidency. It is thus possible that some customs will be re-examined after the 2010 Presidency. That Presidency was held 
during a period of political crisis in Belgium, and some political tensions with regard to climate change have put the crisis in the spotlight.

The factor that mostly determines intergovernmental relations is probably their politicized character. All important decisions are taken at the political level. And although intergovernmental cooperation is often unproblematic at administrative level, cooperation between governments is frequently impeded when ministers are of a different political party. In the case of climate change, there is a manifest cleavage between progressive and conservative positions. In reality, the politicization means that no important or sensitive decisions are taken within intergovernmental mechanisms a few months before each federal or subnational election in Belgium. That situation is prolonged after each election until a government is formed. In the case of the 2007 federal elections, that period lasted for a year, and the country is in a similar situation at the time of writing. The case of climate change policy has shown that those political instabilities can lead to policy failures. Belgium is sometimes unable to take a position on key issues in international negotiations, and the country can lag behind its neighbours with regard to domestic policy-making. While the successive state reforms intended to ease decision-making in a divided country, it appears they had the opposite effect.

\section{References}

Belgisch Staatsblad. 1994. Samenwerkingsakkoord van 8 maart 1994 tussen de Federale Staat, de Gemeenschappen en de Gewesten, met betrekking tot de vertegenwoordiging van het Koninkrijk België in de Ministerraad van de Europese Unie. 17 Nov 1994.

_ 1995. Samenwerkingsakkoord tussen de federale Staat, het Vlaamse Gewest, het Waalse Gewest en het Brusselse Hoofdstedelijk Gewest met betrekking tot het internationaal milieubeleid. 13 Dec 1995.

- 2002. Wet houdende instemming met het Protocol van Kyoto bij het Raamverdrag van de Verenigde Naties inzake klimaatsverandering, en met de Bijlagen A en B, gedaan te Kyoto op 11 december 1997. 26 Sep 2002.

- 2003a. Samenwerkingsakkoord tussen de Federale Staat, de Gemeenschappen en de Gewesten tot wijziging van het samenwerkingsakkoord van 8 maart 1994 tussen de Federale Staat, de Gemeenschappen en de Gewesten met betrekking tot de vertegenwoordiging van het Koninkrijk België in de Ministerraad van de Europese Unie. 13 Feb 2003.

- 2003b. Wet houdende instemming met het Samenwerkingsakkoord tussen de Federale Staat, het Vlaamse Gewest, het Waalse Gewest en het Brussels Hoofdstedelijk Gewest betreffende het opstellen, het uitvoeren en het opvolgen van een Nationaal Klimaatplan, alsook het rapporteren, in het kader van het Raamverdrag van de Verenigde Naties inzake Klimaatverandering en het Protocol van Kyoto, afgesloten te Brussel op 14 november 2002. 15 Jul 2003.

—. 2005. Samenwerkingsakkoord tussen de Federale Staat, het Vlaamse Gewest, het Waalse Gewest en het Brussels Hoofdstedelijk Gewest betreffende de organisatie en het administratief beheer van het gestandaardiseerd en genormaliseerd registersysteem van België overeenkomstig richtlijn 2003/87/EG van het Europees Parlement en de Raad en beschikking 280/2004/EG van het Europees Parlement en de Raad. 23 Sep 2005.

- 2008a. Samenwerkingsakkoord tussen de Federale Overheid, het Vlaamse Gewest, hetWaalse Gewest en het Brussels Hoofdstedelijk Gewest inzake de uitvoering van sommige bepalingen van het Protocol van Kyoto. 19 Feb 2007.

- 2008b. Samenwerkingsakkoord tussen de Federale Staat, het Vlaamse Gewest, het Waalse Gewest en het Brussels Hoofdstedelijk Gewest betreffende de organisatie en het administratief beheer van het gestandaardiseerd en genormaliseerd registersysteem van België overeenkomstig Richtlijn 2003/87/EG van het Europees Parlement en de Raad en Beschikking 280/2004/EG van het Europees Parlement en de Raad. 18 Jun 2008.

Beyers, Jan, and Peter Bursens. 2006. The European Rescue of the Federal State: How Europeanisation Shapes the Belgian State. West European Politics 29 (5): 1057 - 1078. 
Beyers, Jan, Tom Delreux, and Caroline Steensels. 2004. The Europeanisation of Intergovernmental Cooperation and Conflict Resolution In Belgium: The Case of Agriculture. Perspectives on European Politics and Society 5 (1): 103-134.

Bollen, Annemie, Wim De Clercq, Maarten Tas, Luc Wittebolle, Peter Wittoeck, and Marc Van den Bosch. 2006. Kyoto: van beleidskader tot bedriffsstrategie. Wolters Kluwer Belgium NV.

Brans, Marleen, Christophe Pelgrims, and Dieter Hoet. 2005. Politico-administrative Relations under Coalition Governments: The Case of Belgium. In Coalitions of the unwilling: politicians and civil servants in coalition governments, edited by B. G. Peters, T. Verheijen and L. Vass. Bratislava: NISPAcee.

Braun, Dietmar. 2000. Territorial Division of Power and Public Policy-Making: An Overview. In Public Policy and Federalism, edited by D. Braun. Aldershot, Burlington, Singapore \& Sydney: Ashgate.

Brussels Hoofdstedelijk Gewest. 2002. Plan voor structurele verbetering van de luchtkwaliteit en de strijd tegen de opwarming van het klimaat 2002-2010. Brussels: Brussels Institutuut voor Milieubeheer.

Available

from http://www.leefmilieubrussel.be/Templates/Particuliers/informer.aspx?id=3900\&langtype=2067\&det ail=tab3.

Conix, Lise. 2009. Het federale CDM/JI beleid. Evaluatie van de beleidsimplementatie. Master's thesis, Faculteit Sociale Wetenschappen, opleiding Vergelijkende en Internationale Politiek, Katholieke Universiteit Leuven, Leuven.

Coördinatiecomité Internationaal Milieubeleid (CCIM). 2004. Vademecum "onderhandelingen van Europese en multilaterale leefmilieudossiers en de rol van de piloten en de experten" (Vademecum Onderhandelingsmandaat goedgekeurd door de Interministeriële Conferentie Leefmilieu dd 1/04/2004). Brussel: Interministeriële Conferentie Leefmilieu.

Costa, O. 2009. Is Climate Change Changing the EU? The Second Image Reversed in Climate Politics. In The Politics of Climate Change. Environmental Dynamics in International Affairs, edited by P. Harris. London: Routledge.

Council of the EU. 2002. Decision of 25 April 2002 concerning the approval, on behalf of the EC, of the Kyoto Protocol to the United Nations Framework Convention on Climate Change and the joint fulfilment of commitments thereunder (doc. 2002/358/EC). Brussels: Council of the European Union.

De Morgen. 2010. "Onenigheid tussen Magnette en Schauvliege is opgeklopt". De Morgen, 25 Nov 2010.

De Rynck, Stefaan, and Karolien Dezeure. 2006. Policy Convergence and Divergence in Belgium: Education and Health Care. West European Politics 29 (5): 1018-1033.

Debusschere, B. 2010. Ministers vechten om leiding Belgische klimaatdelegatie. De Morgen, 25 Nov 2010.

European Council. 2007. Presidency conclusions. Brussels: European Council 8-9 Mar 2007.

Federale Overheidsdienst Volksgezondheid, Veiligheid van de Voedselketen en Leefmilieu (FOD VVVL). 2008a. Beslissingen van de bijzondere ministerraad in Raversijde (20-21 maart 2004). Federale dienst Klimaatverandering [cited 18 Nov 2010]. Available from http://www.klimaat.be/spip.php?article206\&fs=.

. 2008b. Bevoegdheden. Federale Dienst Klimaatverandering [cited 18 Nov 2010]. Available from http://www.klimaat.be/spip.php?article23\&fs=.

- 2009. Reductiedoelstelling en nationale lastenverdeling. Federale Dienst Klimaatverandering [cited 18 Nov 2010]. Available from http://www.klimaat.be/spip.php?article204\&fs=.

Happaerts, Sander. 2010a. Sustainable development and degrees of autonomy. The challenge of vertical policy integration from the perspective of North Holland, North Rhine-Westphalia, Flanders and Quebec (Working Paper $n^{\circ} 15$ ). Leuven: Steunpunt Duurzame Ontwikkeling. Available from http://www.steunpuntdo.be/E SDO publ CoEfSD.htm.

- 2010b. Sustainable development in Wallonia: trial and error along two tracks of governance (Working Paper $n^{\circ}$ 20). Leuven: Steunpunt Duurzame Ontwikkeling. Available from http://www.steunpuntdo.be/E SDO publ CoEfSD.htm.

Happaerts, Sander, and Karoline Van den Brande. 2010. Sustainable Development between International and Domestic Forces. The Policy Experiences of Quebec, North Rhine-Westphalia and Flanders (Working Paper $\left.n^{\circ} 18\right)$. Leuven: Steunpunt Duurzame Ontwikkeling. Available from http://www.steunpuntdo.be/E SDO publ CoEfSD.htm.

Happaerts, Sander, Karoline Van den Brande, and Hans Bruyninckx. 2010a. Governance for Sustainable Development at the Inter-subnational Level: The Case of the Network of Regional Governments for Sustainable Development (nrg4SD). Regional \& Federal Studies 20 (1): 127-149.

- 2010b. Subnational governments in transnational networks for sustainable development. International Environmental Agreements: Politics, Law and Economics Online First (DOI 10.1007/s10784-010-9128-4).

Henry, Alain, and Nadine Gouzée. 2009. Verkenning van verdelingen van de doelstellingen en de opportuniteiten van het klimaat- en energiepakket in België (Working Paper 17-09). Brussel: Federaal Planbureau. Available from http://www.plan.be/publications/Publication det.php?lang=nl\&TM=30\&IS=63\&KeyPub=899.

Hooghe, Liesbet, Arjan H. Schakel, and Gary Marks. 2008. Appendix A: Profiles of Regional Reform in 42 Countries (1950-2006). Regional \& Federal Studies 18 (2-3): 183-258. 
Jans, Maarten Theo, and Herbert Tombeur. 2000. Living Apart Together: The Belgian Intergovernmental Cooperation in the Domains of Environment and Economy. In Public Policy and Federalism, edited by D. Braun. Aldershot, Burlington, Singapore \& Sydney: Ashgate.

Kanselarij van de Eerste Minister. 2009. Ministerraad van 4 september 2009. dienst Communicatie van de Federale Ministerraad [cited 18 Nov 2010]. Available from http://www.residencepalace.be/repository/news/ee9/nl/ee9f75835b4521e08079fc76f5c7ea97-nl.pdf.

Keating, Michael, and Nicola McEwen. 2005. Introduction: Devolution and Public Policy in Comparative Perspective. Regional \& Federal Studies 15 (4): 413-421.

Lavrysen, L. 2010. Climate Law. Belgian Report. Paper read at the AIDC Conference, 2010, at Washington DC.

Maesschalck, Jeroen, and Steven Van De Walle. 2006. Policy Failure and Corruption in Belgium: Is Federalism to Blame? West European Politics 29 (5): 999 - 1017.

Ministère de la Région wallonne. 2008. Plan Air-Climat. Respirer mieux, c'est vivre mieux. Namur: Ministère de la Région wallonne, Direction générale des Ressources naturelles et de l'Environnement. Available from http://airclimat.wallonie.be/spip/Plan-Air-Climat.html.

Nationale Klimaatcommissie (NKC). 2009. Nationaal klimaatplan van België 2009-2012 (Inventaris van de maatregelen en stand van zaken op 31/12/2008). Brussel: Nationale Klimaatcommissie. Available from http://www.klimaat.be/IMG/pdf/NKP 2009-2012-2.pdf.

Niestroy, Ingeborg. 2005. Sustaining Sustainability. A benchmark study on national strategies towards sustainable development and the impact of councils in nine EU member states, EEAC series, Background study no. 2. Utrecht: Lemma.

Oberthür, S. 2009. The role of the EU in global environmental and climate governance. In The European Union and Global Governance, edited by M. Telo. London: Routledge.

Office of the Governor. 2009. Gov. Schwarzenegger Announces New Coalition of Subnational Leaders to Combat Climate Change (press release $14 \mathrm{Dec}$ 2009). Office of the Governor of the State of California [cited 24 Nov 2010]. Available from http://gov.ca.gov/press-release/14032/.

Peters, B. Guy. 2006. Consociationalism, Corruption and Chocolate: Belgian Exceptionalism. West European Politics 29 (5): 1079 - 1092.

Reuchamps, Min, and François Onclin. 2009. La fédération belge. In Le fédéralisme en Belgique et au Canada. Comparaison sociopolitique, edited by B. Fournier and M. Reuchamps. Bruxelles: De Boeck.

Schunz, Simon. 2010. European Union foreign policy and its effects - a longitudinal study of the EU's influence on the United Nations climate change regime (1991-2009). PhD dissertation, Faculty of Social Sciences, Katholieke Universiteit Leuven, Leuven.

Skogstad, Grace. 2000. Canada: Dual and Executive Federalism, Ineffective Problem-Solving. In Public Policy and Federalism, edited by D. Braun. Aldershot, Burlington, Singapore \& Sydney: Ashgate.

Swenden, Wilfried. 2006. Federalism and Regionalism in Western Europe. A Comparative and Thematic Analysis. Houndmills \& New York: Palgrave Macmillan.

Swenden, Wilfried, Marleen Brans, and Lieven De Winter. 2006. The Politics of Belgium: Institutions and Policy under Bipolar and Centrifugal Federalism. West European Politics 29 (5): 863-873.

Swenden, Wilfried, and Maarten Theo Jans. 2006. 'Will It Stay or Will It Go?' Federalism and the Sustainability of Belgium. West European Politics 29 (5): 877-894.

Van den Brande, Karoline, Sander Happaerts, and Hans Bruyninckx. 2011. Multi-Level Interactions in a Sustainable Development Context: Different Routes for Flanders to CSD Decision-Making. Environmental Policy and Governance 21 (1).

Van Hecke, Karel, and Tania Zgajewski. 2008. The Kyoto Policy of Belgium (Egmont Paper 18). Brussels: Academia Press. Available from http://www.egmontinstitute.be/paperegm/ep18.pdf.

Van Schaik, Louise. 2010. The Sustainability of the EU's Model for Climate Diplomacy. In The New Climate Policies of the European Union. Internal Legislation and Climate Diplomacy, edited by S. Oberthür and M. Pallemaerts. Brussels: VUB Press.

Vlaamse Overheid. 2006. Het Vlaams Klimaatbeleidsplan 2006-2012. Het klimaat verandert. U ook? Brussel: Departement Leefmilieu, Natuur en Energie. Available from http://www.Ine.be/themas/klimaatverandering/vlaams-klimaatbeleidsplan-2006-2012.

Vlaamse Regering. 2009. Een daadkrachtig Vlaanderen in beslissende tijden. Voor een vernieuwende, duurzame en warme samenleving (regeerakkoord Vlaanderen 2009-2014). Brussel: Vlaamse Regering. Available from http://publicaties.vlaanderen.be/eblweb/do/publicatieSessionFacade/publicatieEenvoudigeDetailAction/raadplegen?method=raadplege n\&id=25114.

Vogler, John. 2009. Climate change and EU foreign policy: The negotiation of burden sharing. International Politics 46 (3): 469-490. 


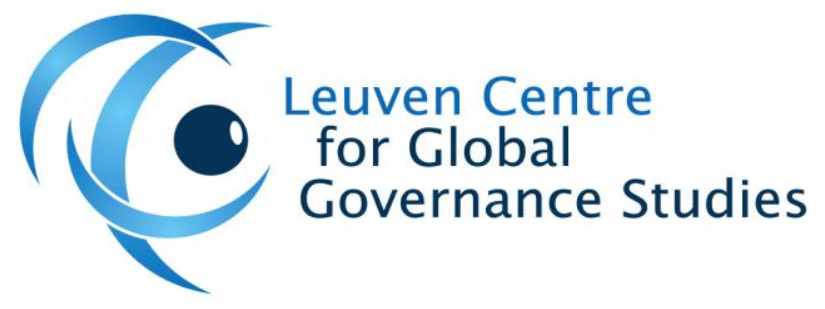

The Leuven Centre for Global Governance Studies is an interdisciplinary research centre of the Humanities and Social Sciences at the Katholieke Universiteit Leuven. It was set up in the Spring of 2007 to promote, support and carry out high-quality international, innovative and interdisciplinary research on global governance. In addition to its fundamental research activities the Centre carries out independent applied research and offers innovative policy advice and solutions to policy-makers on multilateral governance and global public policy issues. In 2010, the Centre has been recognized as a "K.U.Leuven Centre of Excellence".

The Centre brings together talent from throughout the University. It operates on the basis of co-ownership and the strong conviction that interdisciplinary research creates added value to resolve complex multi-faceted international problems. The Centre promotes pioneering projects in law, economics and political science and actively initiates and encourages interdisciplinary, cross-cutting research initiatives in pursuit of solutions to real world problems. The cross-cutting initiatives are thematic projects around which University researchers join forces across disciplines to forge responses to complex global challenges. The cross-cutting initiatives address critical issues in relation to globalization, governance processes and multilateralism, with a particular focus on the following areas: (i) the European Union and global multilateral governance; (ii) trade and sustainable development; (iii) peace and security, including conflict prevention, crisis management and peacebuilding; (iv) human rights, democracy and rule of law.

In full recognition of the complex issues involved, the Centre approaches global governance from a multilevel and multi-actor perspective. The multi-level governance perspective takes the interactions between the various levels of governance (international, European, national, subnational, local) into account, with a particular emphasis on the multifaceted interactions between the United Nations System, the World Trade Organization, the European Union and other regional organizations/actors in global multilateral governance. The multi-actors perspective pertains to the roles and interactions of various actors at different governance levels, these include public authorities, non-governmental organizations and private actors such as corporations.

For more information, please visit the website www.globalgovernancestudies.eu

Leuven Centre for Global Governance Studies

Europahuis, Blijde Inkomststraat 5, 3000 Leuven, Belgium

Tel. ++3216328725 Fax ++3216328726 info@ggs.kuleuven.be

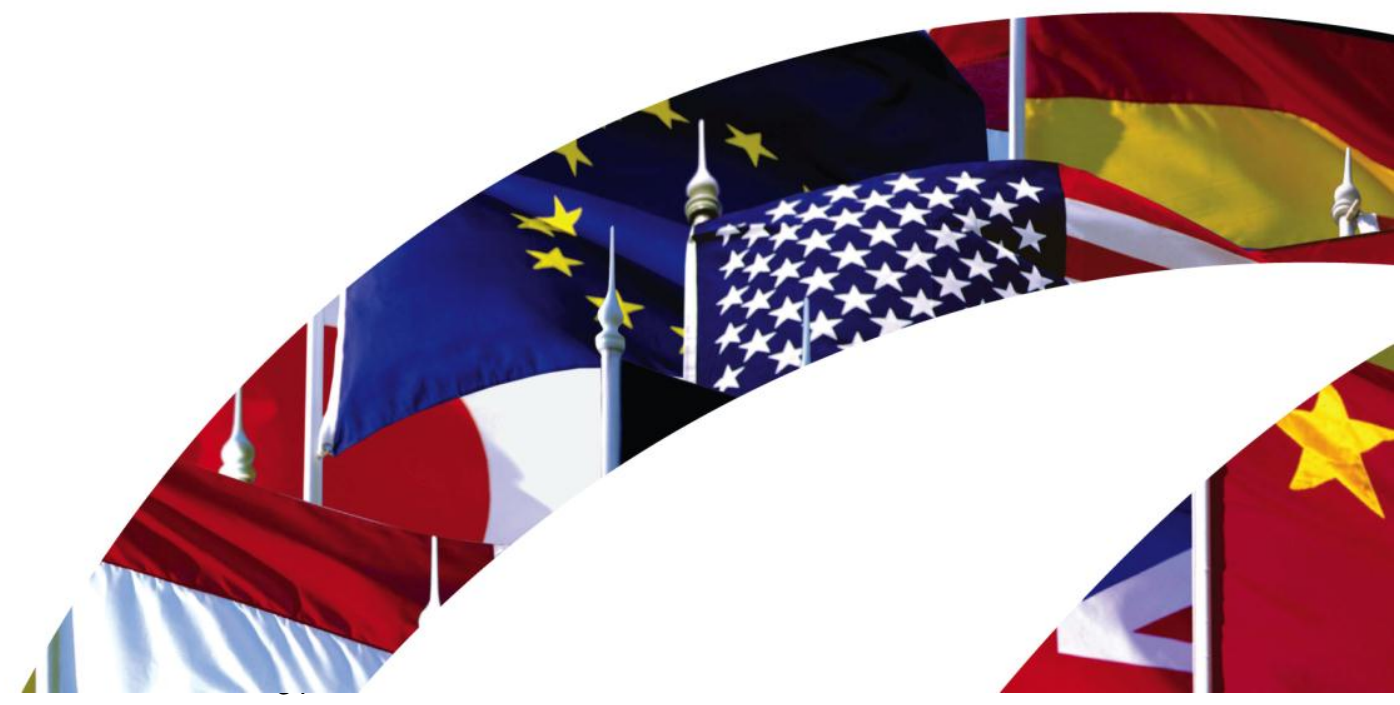

